\title{
An Intra-Hindu Comparative Analysis of Caitanya Vaișnavism's Eco-Theological Motifs
}

\author{
Akshay Gupta ${ }^{1}$ (1) \\ Accepted: 2 March 2021/Published online: 8 April 2021 \\ (c) The Author(s) 2021
}

\begin{abstract}
In the midst of the earth's pressing climate catastrophe, the nexus between ecology and religion merits further investigation. In this article, I attempt to illuminate certain important aspects of this nexus by analyzing various Hindu eco-theological motifs, with a particular focus on those of the Hindu religious tradition known as Caitanya Vaiṣnavism. I will compare and contrast the eco-theological motifs of Caitanya Vaiṣnavism with those of other notable Hindu religious traditions and texts. Ultimately, I attempt to demonstrate that certain Caitanya Vaiṣnava eco-theological motifs can, when properly interpreted and applied, serve as valuable environmentally oriented conceptual resources. I also argue that these eco-theological motifs can offset some of the conceptual pitfalls that limit the effectiveness of various panHindu eco-theological motifs as conceptual resources for environmental amelioration. Although the Caitanya Vaișnava eco-theological framework is not without conceptual hurdles, I nevertheless maintain that Caitanya Vaiṣnava eco-theological motifs are worthy of further reflection.
\end{abstract}

Keywords Eco-theology · Caitanya Vaiṣnavism · Ecology $\cdot$ Religion and the environment

In order to understand the urgency of improving the earth's ecological domains, I will briefly discuss the gravity of the current ecological crisis. Environmentally oriented literature from the last century has pointed out the disruptive effects of environmental degradation. For instance, in 1997, an eminent heart surgeon in New Delhi reported that "patients from outside Delhi have pink lungs" and that "those who reside here have lungs that are charcoal black" (Sidhva \& Bailay, 1997: 45). Unfortunately, since these cautionary remarks were first proclaimed, the earth's ecological situation has further worsened. For instance, Rajendra Pachauri, chairman of the Intergovernmental Panel of Climate Change (IPCC), summarized the findings of

Akshay Gupta

ag2095@cam.ac.uk

1 Faculty of Divinity, University of Cambridge, Cambridge, UK 
the IPCC's Fifth Assessment Report (AR5) by stating that "if the world doesn't do anything about mitigating emissions of greenhouse gases and the extent of climate change continues to increase, then the very social stability of human systems could be at stake" (Quoted in Semeniuk, 2014). For instance, climate change threatens the world's food production and can significantly decrease crop yields (Wheeler \& Von Braun, 2013; Blanc \& Reilly, 2015).

Thus, there is a pressing need to improve the earth's ecological condition. I argue that one strategy to combat the earth's ecological crisis is to re-evaluate and re-interpret the theological presuppositions that can play a crucial role in shaping peoples' ecological behaviors. As governmental policies become increasingly oriented toward the physical sciences and engineering, and as environmentally conscientious individuals strive to discover technological innovations that can address myriad ecological issues, one may question the importance of invoking the resources of religious traditions in the fight for ecological betterment. After all, as Roger Gottlieb notes, one can argue that "what a particular religion says and what that religion's (self-proclaimed) followers actually do are two very different things" and thus "most people, most of the time, go along with whatever is being done by everyone else and do so with little concern beyond their family, neighborhood, or village" (Gottlieb, 2006: 9).

However, as Gottlieb later mentions, during times of strife, "large numbers of people actually live out the highest aspirations of their moral code, whether that code is religious or secular, anthropocentric or environmental" (Gottlieb, 2006: 9). Thus, he argues that peoples' moral behavior can be guided by their religious beliefs (Gottlieb, 2006: 9). Other scholars also reaffirm the causal role that religious beliefs play in shaping peoples' behavior. For instance, Lynn White states, "what people do about their ecology depends on what they think about themselves in relation to things around them. Human ecology is deeply conditioned by the beliefs about our nature and destiny - that is, by religion" (White, 1967: 1205). Thus, according to White, one's metaphysical presuppositions indeed play a large role in shaping their ecological behavior. As Vasudha Narayanan notes, theologians like Rosemary Reuther and Carol Adams also believe that peoples' attitudes and actions derive existential momentum from, and are also oriented toward, their fundamental worldviews, which must be modified in order for people's behavioral patterns to change (Narayanan, 1997: 296).

I too would argue that religious beliefs are important components within the various social, psychological, and ethical matrices that constitute an individual's moral and behavioral framework. While religious beliefs may not be the only psychodynamic variable that motivates individuals' attitudes and actions, I believe that such beliefs are significant enough to warrant a closer interrogation of their textual bases and theological underpinnings. Thus, in this article, I will critically examine some important $\mathrm{Hindu}^{1}$ theological frameworks along with certain features of the theological framework of the Caitanya Vaiṣnava tradition. My motivations for doing so are to pursue two eco-theological aims put forth by

\footnotetext{
${ }^{1}$ I understand Hinduism to be an umbrella term for the various religious traditions that have historically developed on the Indian subcontinent and are not subsumed under the groupings of religious traditions known as Buddhism, Jainism, and Sikhism.
} 
Christopher Fici, namely, (1) to "re-discover and amplify textual, ritual, pragmatic, and experiential elements [within these theological frameworks] which inspire and reinforce ecologically sound, wise, just, and compassionate relationship to planetary creation" and (2) to "re-discover, critique, and resist those [theological] elements" that "reinforce a denigrative, destructive relationship to Earthly creation" (Fici, 2020: 38).

One may question the importance of focusing an eco-theological lens on Hindu religious traditions to begin with. I argue that there are several reasons why Hindu eco-theological inquiry is a worthwhile endeavor. First, at the end of the last millennium, India was described as having "the world's largest environmental movement" (Peritore, 1993: 807). This claim was also echoed in the pioneering edited volume Hinduism and Ecology, edited by Christopher Chapple and Mary Tucker, wherein Chapple noted that India had over 950 NGOs dedicated to addressing environmental concerns (Chapple, 2000: xxxiii-xlix). India's efforts to combat the ecological crisis continue today, as evidenced by the ecological activism of numerous environmentally oriented groups such as the Swadhyayis (Jain, 2019: 272). Moreover, Hindu thought contains various conceptual resources that can be drawn upon to inspire ecologically oriented action. For instance, as I will explain later in this article, various Hindu religious traditions and texts have elevated the ontological importance of nature by sacralizing it or by encasing it with spiritual significance. Such Hindu eco-theological motifs have thus led Chapple to state, "the Hindu religion, with its vast storehouse of text, ritual, and spirituality, can help contribute both theoretical and practical responses to this [environmental crisis]" (Chapple, 2000: xivii).

Yet, it is worth noting that Gerald Larson cautions us against using the conceptual resources within South Asian theological frameworks to construct a prescriptive ethical framework for addressing the environmental crisis, since these conceptual resources are deeply embedded within certain sociocultural contexts and may not be applicable outside such contexts (Larson, 1989: 274). I acknowledge that South Asian conceptual resources can be less effective when they are employed outside of such contexts. However, I deny the thesis that South Asian conceptual resources are entirely ineffective when abstracted from these contexts. I argue that it is absurd to think that individuals are incapable of deriving any measure of inspiration from concepts that originate outside of their immediate sociocultural context. For example, I think few individuals would claim that an American who studies Eastern philosophy could receive no educational benefit from such study. Or, let us say that someone from America has travelled to India for the first time. Most of us would find it hard to believe that such a person would leave India having had none of their culturally informed presuppositions challenged or altered to some degree. Thus, I argue that any individual who might implement some Caitanya Vaișnava eco-theological motifs into their belief structure can benefit from these eco-theological insights, especially if these insights can inspire them to modify or alter their ecologically harmful habits in some concrete ways with realworld impact.

In this article, I primarily aim to highlight some of the eco-theological contributions that Caitanya Vaiṣnavism offers through its theological insights. However, in 
order for these eco-theological contributions to be properly appreciated, I will first describe some environmentally oriented conceptual resources within other strands of Hindu thought.

\section{Hindu Theological Motifs That Can Inspire Ecological Change}

One Hindu theological leitmotif with positive environmental implications is the divinization of nature. As early as the time when the Rgveda samhitās were compiled (c. 1500-1200 BCE), one finds numerous Vedic hymns that deify certain aspects of nature such as earth $(p r t h v \bar{\imath})$, fire (agni), and wind (vāyu) (Nelson, 2008, 98 ). It is no surprise then that the earth has been spiritually reconfigured into a goddess $(d e v \bar{l})$ by several Hindu texts and thinkers throughout history. As early as the Atharvaveda (c. $1000 \mathrm{BCE}$ ), there were hymns to the earth that addressed her as a goddess, Devī Vasundharā, and considered her to be a nurturing other (Nelson, 2008: 98). A couple of millennia later, some strands of the Śrī Vaiṣnava tradition, which was based on the life and teachings of Rāmānuja (c. 1017-1137 CE), began to magnify the earth's ontological status by revering her as the spouse of Viṣnu (Sharma, 1998: 56; Mumme, 1998).

Hindu religious traditions have also sacralized, or envisioned as embodying a spiritual dynamism, other natural phenomena such as rivers as well as certain types of plants. For instance, the river Ganges and the tulasi plant are often depicted as goddesses within Hindu theological universes (Sherma, 1998: 95-96; Nagarajan, 1998: 283-284). Moreover, on a macro-cosmic level, the entire natural world has been sacralized as an integral ontological component of the divine by certain Hindu thinkers and theological frameworks. For instance, according to Anantanand Rambachan's interpretation of classical Advaita Vedānta, ${ }^{2}$ which is a soteriological discipline that was systematized by Śankara $\left(c .9^{\text {th }}\right.$ century CE), the natural world can be viewed as an emanation of God and thus valued as sacred (Rambachan, 2014: 138). Rambachan also adds that God's deliberate decision to produce the world should also impel us to view it with greater reverence and also discourage us from attempting to trivialize its ontological importance (Rambachan, 2014: 139). Moreover, within Śrī Vaiṣnavism, the relationship between God and the natural world is analogous to the relationship between the transcendent spiritual self and its body (śarīra) (Narayanan, 2001: 185; Barua, 2010: 15). In such a theological framework, the natural world can therefore be seen as the very body of God, thus signifying that the natural world is not ontologically distinct from God but instead intimately connected with God.

A similar theological perspective is also reinforced by the notion of divine theocentrism, which acknowledges "the pervasive presence of the divine within the cosmos" (Scheid, 2016: 130). This view finds support from Hindu scriptures such as the Bhagavadgītā (c. 500 BCE-200 CE) (henceforth BhG),

\footnotetext{
2 Vedānta is an umbrella term for systems of philosophical inquiry and soteriological practice that seek to understand the final spiritual aim of the Vedas. It's tripartite textual canon (prasthānatraȳ) comprises the Bhagavadgīta, the Brahmasūtra (c. $5^{\text {th }}$ century CE), and the Upanișads (c. 800-300 BCE).
} 
which contains several verses that support a sacralized view of nature. For instance, $B h G 6.30^{3}$ states that Kṛṣna is not lost to one who sees him in all things and all things in him (additional related verses include 4.35, 6.29, 7.7-9, 10.32, and 15.13-14) (Nelson, 2000: 153). Other scriptural verses like Bhāgavatapurāna $\left(c .9^{\text {th }}\right.$ to $10^{\text {th }}$ century CE) (henceforth $B h P$ ) $11.2 .45^{4}$ also echo this motif.

These evocative sacralizations of the earth, its various natural features, and, in certain contexts, the natural world itself, along with the view that nature embodies divine presence, are ecologically highly significant because they provide individuals with a greater moral incentive and orientation to properly honor the earth and the natural world. When nature is viewed as a sacred entity, theists are motivated to treat it with greater respect and ensure that it remains in a healthy ecological condition. In contrast, when nature is viewed as a profane entity consisting merely of a stockpile of resources that are meant for human exploitation, humans will be demotivated from properly caring for the earth and acting for its long-term flourishing.

The eco-theological perspectives contained within Hindu theological and textual frameworks are also significant because they can orient individuals toward an ecological worldview that resonates with Arne Naess's notion of deep ecology. In contrast to "shallow ecology," which Naess defines as "the fight against pollution and resource depletion [which aims to improve] the health and affluence of people in the developed countries" (Naess, 1973: 95), "deep ecology" is constituted by certain tenets such as (1) "rejection of the man-environment image in favor of the relational, total-field image" and (2) "biospherical egalitarianism" (Naess, 1973: 95). According to Kiyokazu Okita, “in deep ecology, the paradigm shifts from an anthropocentric to an 'ecocentric' world view, according to which human beings recognize themselves as an organic part of nature and according to which the significance of non-human beings is not measured based on their usefulness to human beings" (Okita, 2009: 3).

According to Naess, this "ecocentric" view of nature is promoted when the self's identity is "widened and deepened so that protection of free Nature is felt and conceived as protection of ourselves" (Naess, 1987: 39-40). When this deep immersion of the self in wider ecological milieus occurs, the self needs "no moral exhortation to show care" to the environment (Naess, 1987: 39-40). Thus, at least in theory, perspectival changes that contribute toward a "deep ecology" environmental worldview, such as those contained within the abovementioned Hindu theological and textual frameworks, can inspire and sustain behavioral changes that lead to greater environmental concern.

As O.P. Dwivedi mentions, such eco-centric perspectival changes can thus lead to a vision of vasudhaiva kutumbakam, or, "the extended family of the earth" (Dwivedi, 2006: 167). This worldview implies "that the planet we inhabit and of

\footnotetext{
3 yo māim paśyati sarvatra sarvaì ca mayi paśyati / tasyāham na praṇaśyāmi sa ca me na praṇaśyati // (Schweig, 2010: 297).

4 sarva-bhūteșu yaḥ paśyed bhagavad-bhāvam ātmanaḥ / bhūtāni bhagavaty ātmany eșa bhāgavatottamah // "The highest devotee is one who sees the self's nature, which is like that of God, in all living beings and who sees all living beings in God" (Śāstrī, 1965-1975, Canto 11: pg. 84).
} 
which we are all citizens_-Planet Earth — is a single, living, pulsating entity" and "that the human race, in the final analysis is an interlocking, extended family-vasudhaiva kutumbakam as the Veda has it" (Singh, 1991: 123). If individuals were to adhere to this ecological worldview, their actions could become oriented toward improvement of the earth's welfare.

In addition to divinizing or transfiguring the earth, Hindu scriptural texts ascribe greater ontological value to nature by viewing it as a spiritual guide. For instance, as Klaus Klostermaier has explained, the $B h P$ narrates the story of an ascetic who learns various spiritually beneficial lessons from nature (Klostermaier, 2007: 477478). For instance, BhP $11.7 .37^{5}$ explains that the earth taught this ascetic to tolerate the aggressive actions of others by understanding that all living beings are acting according to their fate (daiva). At BhP 11.7.38, ${ }^{6}$ the ascetic adds that mountains taught him to dedicate his actions for the sake of others and that trees taught him that one's very self is meant to be used for the welfare of others. The ascetic also explains that the wind taught him to understand that the transcendent self, though interacting with a physical body, remains unaffected by the physical body's qualities, just as air interacts with fragrances while being unaffected by them (BhP 11.7.41 $\left.{ }^{7}\right)$. Moreover, the sun, by its example of evaporating bodies of water and then later distributing the water, has taught the ascetic how to accept various objects and later give them up at the appropriate time $\left(B h P 11.7 .50^{8}\right)$. Thus, through this worldview contained within the $B h P$, humans would have an incentive to respect the earth as a guru-like figure, who, at least within certain Hindu contexts, is treated with deep reverence (Forsthoefel and Humes 2005: 3).

Another Hindu religious motif that carries significant ecological implications is dharma. Dharma is a highly polyvalent word and hence difficult word to translate to English since its definition is context-specific. However, it can be roughly defined as "righteous conduct' or 'one's moral duty." The notion of dharma can have powerful positive environmental impacts when environmental awareness is embedded within conceptual frames shaped by dharmic ideals because individuals, within Indic contexts, often draw upon these dharmic ideals to shape their moral behavior and also attempt to embody and enact such ideals. For instance, as Pankaj Jain has shown, various religious communities such as the Swadhyayis have constructed a dharmic framework centered around preserving their natural resources (Jain, 2011: 272).

Furthermore, ahims $\bar{a}$, or non-violence, is yet another Hindu ethical principle with positive ecological implications. Though it is not a Hindu ethic that is directly pronounced in the Vedas, ahims $\bar{a}$ has become a central feature of Hindu ethical frameworks. Thus, in the $B h G$ and the $B h P$, we find ahims $\bar{a}$ listed as a

\footnotetext{
5 bhūtair ākramyamāṇo 'pi dhīro daiva-vaśānugaịh / tad vidvān na calen mārgād anvaśikșam kṣiter vratam // (Ś̄àstrī, 1965-1975, Canto 11: pgs. 355-356).

6 śaśvat parārtha-sarvehah parārthaikānta-sambhavah / sādhuḥ śikṣeta bhū-bhrtto naga-śiṣyah parātmatām // (Śāstrī, 1965-1975, Canto 11: pg. 356).

7 pārthiveșv iha deheșu praviștas tad-gunāśrayah / guṇair na yujyate yogi gandhair vāyur ivātma-dṛk // (Śāstrī, 1965-1975, Canto 11: pg. 360).

8 guṇair guṇān upādatte yathā-kālaṃ vimuñcati / na teșu yujyate yogi gobhir gā iva go-patiḥ // (Śāstrī, 1965-1975, Canto 11: pg. 368).
} 
spiritual virtue for individuals to cultivate (see $B h G 16.2$ and $B h P$ 3.28.4, 7.11.8, 11.17.21, 11.19.33).

Edwin Bryant explains that as the principle of ahims $\bar{a}$ developed stronger roots on the religious landscape, the animal sacrifices of the Vedic age later became reinterpreted and re-envisioned in order to accommodate this growing non-violent ethos (Bryant, 2006: 194; 202). ${ }^{9}$ For instance, the BhP explains that although some violent individuals perform animal sacrifice, there is no prescriptive imperative (na codan $\bar{a}$ ) to do so $\left(B h P 11.21 .29^{10}\right)$. The $B h P$ also narrates the story of certain performers of animal sacrifice who received a vision in which they were to be violently assaulted by the same animals that they had killed, thus indicating that animal sacrifices carry serious negative karmic repercussions (BhP 4.25.7- $8^{11}$ ). It is also worth noting that in the thirteenth century, Madhva advocated for a replacement of living animals with animal effigies whenever Vedic rituals were performed (Houben, 1999: 156).

It is no surprise then, that ahims $\bar{a}$ eventually extends out into the practice of vegetarianism. For instance, the Manusamhitā (c. 500 BCE-200 CE) explains that meat-eating is permissible only in ritual contexts (Manu $5.31 ;^{12} 5.36^{13}$ ), and, within these contexts, the various herbs, trees, and animals that are ritually slaughtered or offered are believed to attain a higher existence in their next life, as does the brähmana priest who performs the sacrifice (Manu 5.42 ${ }^{14}$ ). However, outside of this sacrificial setting, Manu strongly cautions against meat consumption. For instance, he states that someone who slaughters animals outside a ritual context will be slain the same number of times as the number of hairs on the killed animals' bodies (Manu 5.38 ${ }^{15}$ ). Manu also describes a person who augments their flesh with that of others as the greatest of sinners (Manu 5.52 ${ }^{16}$ ). Yet, Manu is not alone in his proscription of a non-vegetarian diet outside of ritual settings. As Bryant notes, in the Mahābhärata (c. 400 BCE-400 CE) (Aśvamedha Parva 114), the warrior Bhișma states that eating meat is like eating the flesh of one's own son and that meat consumption deprives one of the pleasures of heaven (Bryant, 2006: 199). The BhP also proscribes meat-eating, and notably, this

\footnotetext{
${ }^{9}$ It is also worth mentioning that some hymns in the Rgveda euphemize the violence enacted in animal sacrifices by asserting that the sacrificial animals are not killed but instead sent to the gods (Vidal et al., 2003; see also Rgveda 1.162.21).

10 te me matam avijñāya parokṣam viṣayātmakāh / himināyām yadi rāgaḥ syād yajña eva na codanā // $(11,924)$.

11 BhP 4.25 .7 - bhoḥ bhoḥ prajāpate rājan paśūn paśya tvayādhvare / saṃjñāpitā̃n jūva-sañghān nirghrnena sahasraśạ̣ // (Śāstrī, 1965-1975, Canto 4: pg. 611).

BhP 4.25.8 - ete tvām sampratīkṣante smaranto vaiśasam tava / samparetam ayah-kūtaiś chindanty utthita-manyavah // (Śāstrī, 1965-1975, Canto 4: pg., 611).

12 yajñāya jagdhir māmsasyetyeșa daivo vidhih smṛtah / ato anyathā pravrttis tu rākșaso vidhir ucyate // (Jolly, 1887: 100).

13 asan்skṛtān paśūn mantrair nādyād viprah kathạ̣ cana / mantrais tu sañskṛtān adyāc chāsvatam vidhim āsthitah (Jolly, 1887: 100).

14 eșv artheșu paśūn himsan veda-tattvārtha-vid dvijaḥ / ātmanām ca paśuś caiva gamayaty uttamam gatim // (Jolly, 1887: 101).

15 yāvanti paśuromāṇi tāvat kṛtvo ha māraṇam / vṛthāpaṡughna prāpnoti pretya janmani janmani // (Jolly, 1887: 100).

16 svamāmsam paramāmsena yo vardhayitum icchati / anabhyarcya piț̣n devān na tato anyo asty apunyakrta (Jolly, 1887: 102).
} 
prohibition holds even within sacrificial contexts $(B h P$ 7.15.717). Thus, within various Hindu scriptural contexts, there are imperatives to abstain from consuming meat.

The ecological implications of individuals' adherence to a cruelty-free diet are well-documented. For instance, as previous studies (Baroni et al., 2006; Harold et al., 2009; Reijnders \& Soret, 2003) have found, vegetarian diets have less environmental impact than non-vegetarian ones. Moreover, Baroni et al. (2006) have found that vegan diets have the least environmental impact. Thus, it is no surprise that scholars such as Pankaj Jain claim that the adoption of a cruelty-free diet is "one of the most important dharmic lessons inspired by Indic traditions" that can help us to combat the ecological and climate crisis (Jain, 2011: 122). Given the cruelty embedded within the current dairy industry and the environmental benefits of non-dairy preferences, one may also argue that veganism is an appropriate diet to adopt if one wishes to maximize their observance of ahims $\bar{a}$ in our current times. Therefore, if the principle of ahims $\bar{a}$ can encourage more individuals to adopt a vegan or a vegetarian diet, then we could expect the ecological condition to improve.

In addition to providing eco-theological concepts from textual frameworks, Hindu thought also contains some practical strategies to combat the ecological crisis. For instance, through his ethical and socio-economic thought, Gandhi provided the basis for a model of environmental ethics that offers certain pragmatic solutions for the earth's ecological problems. There are four main ethical principles that serve as the foundation for Gandhi's ecological thought. According to Larry Shinn, these ethical principles are (1) satya, or truth, (2) ahimsā, (3) tapas, or voluntary hardship undergone for spiritual self-purification, and (4) svarāj, or self-governance (Shinn, 2000: 221-222). Gandhi's socio-economic views are shaped by, and densely rooted in, these ethical principles. For instance, because of his vision of a self-governed India, Gandhi placed a strong emphasis on the generation of economic self-sufficiency, which he believed could be achieved through self-sufficient village-based economies that would produce adequate goods, clothing, and shelter (Radder, 2015: 143). Moreover, Gandhi's adherence to ahimsā led him to denounce animal slaughter and instead advocate for the protection of cows. For instance, Gandhi once stated, "cow protection is dearer to me than my very life" (Burgat, 2004: 233). Yet, in criticizing cow slaughter, Gandhi also recognized that there were practical dimensions to cow protection that needed to be considered. For example, Gandhi stated that Indians needed to learn about the economic benefits of animal husbandry so that "killing animals would become [viewed as] an economic absurdity" (Burgat, 2004: 234). Gandhi also claimed that an awareness of the utility of cow products (milk, dung, and urine), the oxen's service, and the proper utilization of cow carcasses (hide and meat) was necessary in order for cow protection to be viewed as a superior economic alternative to cow slaughter (Burgat, 2004: 244).

These Gandhian economic and environmental ideals have inspired several environmentalist groups and individuals. For instance, Sunderlal Bahugana and Chandi Prasad Bhatt, two of India's most renowned environments, who are known for

\footnotetext{
${ }^{17}$ na dadyād àmișàm śrāddhe na cādyād dharma-tattvavit / muny-annaih syāt parā prītir yathā na paśu-himsayā // (Śāstrī, 1965-1975, Canto 7: pg. 520).
} 
playing a central role in the Chipko Andolan ("Hug-the-Tree Movement"), were heavily influenced by Gandhian principles (Gadgil \& Guha, 1992). For example, Bahugana and his wife were among the first workers trained by the Gandhian ideal of sarvodaya, or equal prosperity and welfare for all (Guha, 1998: 66). Bahugana's application of Gandhian principles also includes his adoption of hunger strikes, which led, in one instance in 1996, to fast for 74 days (Nelson, 2008: 108). Moreover, Bhatt's ecological activist vision, which aimed to combat commercial forestry through the non-violent technique of hugging those trees that were marked for removal, was inspired by Gandhi's example of non-violent protest (Radder, 2015: 145).

The Gandhian principle of non-violent protest also influenced Baba Amte and Medha Patkar, who were two significant leaders of the Narmada Bachao Andolan ("Save-the-Narmadā-Movement") (Radder, 2015: 145). They aimed to stop the Narmada dam project, which aimed to construct a dam on the Narmada river, which would lead to the flooding of dozens of nearby villages of peasant and indigenous groups. Through non-violent protests, inspired by Gandhi's own example, Amte, Patkar, and their followers were able to delay the construction of the dam and cause the World Bank to withdraw the funds that it had previously offered in support of the project (Klostermaier, 2007: 488).

Within certain Indian social spaces, there are also environmental activist groups other than those inspired primarily by Gandhi. For example, the Swadhyayis, led by its founder Pandurang Shastri Athavale (1920-2003), are a religious movement that arose in the mid-twentieth century in Western India. One of the environmentally oriented projects of the Swadhyayis is their construction of vrksa-mandiras ("treetemples"). These tree-temples, some of which are built on land that was previously thought to be barren, are arboreal matrices comprising trees such as mango trees and sapodilla trees. The construction of these tree-temples is inspired by the Swadhyayis' theological framework, which views trees as gods and also recognizes that divinity can be manifested within botanical entities (Jain, 2019: 267-268). Within this theological framework, one also hears the Upanisadic notion of the "Indwelling God," which asserts that God resides within all selves regardless of their caste, class, zoological species, or religion. Thus, the Swadhyayis revere the earth, water, trees, and cattle due to their environmentally sensitive outlook, and for this reason, Jain highlights the ecological sustainability of the Swadhyayi's cultural practices (Jain, 2019: 267).

\section{Problems Employing Hindu Eco-Theological Conceptual Resources}

The varied Hindu environmental frameworks that I have described thus illustrate that the Hindu religious traditions have a rich array of conceptual resources that can be creatively employed and hermeneutically retrieved in order to inspire individuals to improve our current ecological condition. However, properly channeling these resources so that they can effectively combat the environmental crisis is no straightforward or easy endeavor. As various scholars have pointed out, many of the environmentally oriented conceptual resources that the Hindu religious traditions offer 
are beset with several issues that problematize their employment or compromise their efficacy as tools for environmental amelioration. However, as I will argue, the theological resources within Caitanya Vaișnavism can, with proper interpretation and application, offset some of the negative implications of the conceptual pitfalls that problematize the employment of certain Hindu eco-theological motifs as environmentally oriented conceptual resources. In order to contextualize these pitfalls, I will now explain them.

One common challenge raised against certain theological frameworks that are said to promote an "otherworldly" attitude, such as Advaita Vedānta and Śr̄̄ Vaișṇavism, is that they discourage any meaningful socially proactive engagement with the physical world, including attempts to alleviate the current environmental crisis (Nelson, 1998: 62; 70). ${ }^{18}$ This challenge is not insurmountable however, and scholars such as Rambachan and Patricia Mumme have argued that these two traditions can interpret their respective theological framework in a manner that affirms worldly engagement. For instance, Rambachan argues that this world is to be celebrated as an expression of brahman, ${ }^{19}$ and he adds that when a spiritually perfected self dispels their ignorance, they do not view the world as illusory, but rather, they see the world as non-different from brahman (Rambachan, 2006: 79-80). Thus, Rambachan challenges the interpretations of classical Advaita Vedānta that declare this physical world to be merely an illusion that does not truly exist (Rambachan, 2014: 7). Instead, he advocates for an interpretation of classical Advaita Vedānta that does not devalue the world and instead recasts it in a positive light "as the outcome of the intentional creativity of brahman," thus incentivizing Advaitins to participate in forms of social activism (Rambachan, 2014: 7). Furthermore, Mumme argues that Śrī Vaișnavas have an incentive to undertake ecological activism since service that aims to support the world (loka-sangraha) is encompassed within service to God, which is the self's ultimate goal and destiny, even for selves that have fulfilled the soteriological aim of surrendering to God (prapatti) (Mumme, 1998: 147-148).

Thus, the theological frameworks of certain Hindu religious traditions such as Advaita Vedānta and Śrī Vaișṇavism do not need to be interpreted in a manner that discourages participation in forms of social activism. Nevertheless, I argue that the tendency to focus on one's soteriological pursuits at the expense of the physical world can be present within theological frameworks that place a strong emphasis on otherworldly achievements, and thus, this tendency must be addressed when offering theologically grounded conceptual resources for environmental amelioration.

Another problematic feature of Hindu theological frameworks is the set of interrelated issues that arise when sacred geographical entities are feminized. As Rita Sherma explains, "when natural sites and phenomena are feminized, they are also frequently maternalized and become thereby symbolically associated with the complex of expectations surrounding motherhood in India" (Sherma, 1998: 96). Sherma

\footnotetext{
18 A similar critique has also been presented against the $B h G$ as well due to the text's otherworldly orientation (Nelson, 2000: 151-153).

19 The closest English equivalent for the term brahman is "God," although the conceptualization of brahman within Hindu theological frameworks can differ from Judeo-Christian notions of God.
} 
adds that this maternalization is problematic because a woman's honor in Indian patriarchal structures is based on her self-negation, ability to endure hardships for the benefit of her dependents, and willingness to selflessly cater to the needs of others without considering her own (Sherma, 1998: 96). Thus, when geographical entities are sacralized and consequently feminized, these androcentric attitudes can become mapped onto these natural entities, and men can develop an exploitive mentality that enables them to justify their apathy toward the condition of natural resources.

The feminization of natural entities can also reinforce patriarchal values, particularly when nature is designated as a "damsel in distress" who must be rescued by a masculine hero (Mumme, 1998: 155). The Varāha narrative is one illustration of this motif. As the story goes, an individual named Hiranyākṣa caused the earth to sink into a cosmic ocean located in the lower regions of the universe. Vișu, assuming the form of a boar, rescued the earth from the depths of this ocean and slayed the heinous Hiranyākșa (BhP 3.19; Tagare \& Shastri, 1950: 324-328). Although this narrative appears to support an environmentally conscious outlook at a first glance, eco-feminists have decried such types of narratives, for they promote the notion that women, identified with nature, are helpless and require the assistance of male authorities in order to prosper (Heller, 1993). Therefore, although the sacralization of geographical entities has the potential to inspire greater concern for nature, the patriarchal connotations of such sacralization must also be kept in mind.

Moreover, although some Hindu theological frameworks sacralize nature, they do so in a compartmentalized manner that selectively designates certain geographical entities as sacred, while labeling other geographical entities as profane. For instance, as Frank Korom, mentions, when pilgrims come to the sacred city of Varanasi and wish to walk along the designated pilgrimage path, they are instructed to circumambulate the city in the clockwise direction so that they can always keep the city on their right (Korom, 1998, 242). These pilgrims are also instructed not to defecate or urinate on the right side of the path, for such acts would contaminate the city. Instead, they are told to urinate or defecate on the left side of the path on what is considered to be profane ground. Thus, the Hindu tendency to sacralize certain entities does not necessarily have positive ecological implications since only select geographical regions and entities are treated with reverence in real-world contexts instead of nature as a whole.

The sacralization of nature is also problematic because it can cause individuals to view the sacralized entities as too pure to be contaminated, thus discouraging any attempts to clean them. For instance, as Korom notes, many Hindus in Varanasi believe that the Ganges' spiritual purity prevents it from being truly polluted (Korom, 1998: 243). As Korom also points out, there are numerous stories within some Hindu religious worlds that describe the miraculous effects of the Ganges' water. For instance, it is believed that heinous individuals can be pardoned for their misdeeds and can become fit to enter heaven or be made impervious to their karmic consequences simply by coming in contact with the water of Ganges or with individuals that have come in contact with such water (Korom, 1998: 243). When individuals develop such a high degree of reverence for the Ganges, they may thus find it unnecessary to cleanse the Ganges of her material contaminants. 
Finally, there are some real-world problems with the pragmatic implementations of Hindu environmental frameworks such as Gandhian economics. As Chapple points out, agrarian and village models of sustenance fail to bear "direct relevance for the burgeoning urban life that hundreds of millions of people in India have embraced in the past few decades" (Chapple, 1998: 31). Given that this demographic is largely responsible for the world's worsening environment condition, the inability of Gandhian economics to offer an appealing alternative to modern urbanized life serious limits its efficacy as a model for positive ecological transformation.

\section{Analyzing Caitanya Vaiṣṇava Eco-Theological Motifs}

Thus, Hindu theological frameworks provide various conceptual resources that can be employed to inspire and structure environmental activism, although these conceptual resources are beset with various difficulties, as I have just indicated. I now argue that certain Caitanya Vaiṣnava eco-theological motifs, when properly interpreted and applied, can serve as conceptual resources that can inspire a more conscious environmental outlook, while minimizing or avoiding some of the various conceptual difficulties that I have outlined in this article. I do not intend to claim that these difficulties are entirely absent within Caitanya Vaișnava eco-theological motifs, nor am I arguing that these motifs are inherently superior to the eco-theological motifs of other related traditions such as Advaita Vedānta or Śrī Vaiṣnavism. Nevertheless, I do maintain that Caitanya Vaiṣnava eco-theological motifs are capable of inspiring positive environmentally oriented action and are worthy of further reflection.

However, before proceeding to describe these motifs, I will first provide a brief historical and theological backdrop to Caitanya Vaișnavism. Caitanya Vaișnavism is based on the life and teachings of Caitanya (1486-1534 CE), who initiated a widespread movement of loving devotion to Kṛṣna (Krṣṇa-bhakti) primarily in parts of eastern India such as present-day West Bengal and Orissa. This devotional epicenter later encompassed the Vṛndāvana area in northern India as well (Bryant, 2017, Kindle Location 349). The Caitanya Vaiṣnava tradition, like other Vaiṣnava traditions, which emphasize the spiritual importance of cultivating devotion (bhakti) to Vișnu or Krș̣na, is centered on cultivating intensely affective forms of devotional love to Kṛșna, who is held to be the supremely personal God (Sardella, 2012: 182183). Crucially, Kṛṣna is worshipped along with his divine consort Rādhā, who is the embodiment of Kṛșna's pleasure giving energy (hlädini-śakti) and the supreme Goddess (Holdrege, 2013: 160).

Prominent among Caitanya's immediate followers were the six Gosvāmins, who are the following six exegete-theologians: Sanātana Gosvāmin (c. 1488-1588 CE), Rūpa Gosvāmin (c. 1489-1564 CE), Raghunātha Gosvāmin (c. 1495-1571 CE), Gopāla Bhațta Gosvāmin (c. 1503-1578 CE), Raghunātha Bhațtạ Gosvāmin (c. 1505-1579 CE), and Jīva Gosvāmin (c. 1513-1598 CE). It should be noted in this context that there is tradition of Caitanya Vaiṣnavism (the Caitanya Vaișnava Vedānta tradition, henceforth CVV), which is affiliated with these six Gosvāmins and especially Jivva that engages with and frames its theological framework within Vedānta (for an in-depth exploration of Jĩva's engagement with Vedānta, see Gupta 
2007; see also Okita, 2014 for a discussion of how Baladeva Vidyābhūṣaṇa (c. 18 ${ }^{\text {th }}$ century $\mathrm{CE}$ ), one prominent theologian within the CVV, engaged with Vedānta). I will continue to describe various features of the CVV's theological framework throughout the rest of this article. However, a comprehensive description of this framework is beyond the scope of this article. For now, it suffices to say that the CVV's theological framework holds that finite selves, who are ontologically connected with God as one of God's energies (śaktis) but who are distinct individuals from God nonetheless, can achieve the ultimate soteriological goal of pure unalloyed love of Krșna (preman) through the ongoing performance and cultivation of Kṛṣna-bhakti (Kavirāja \& Bhaktivedanta Swami Prabhupāda, 1998a: 884). It is also important to note that two authoritative Hindu scriptural texts within the CVV are the $B h G$ and the $B h P$. Notably, Jivva has employed various hermeneutical strategies that situate the $B h P$ as a fully epistemically authoritative scriptural text. It is beyond the scope of this article to discuss these strategies; however, the reader can consult (Bryant, 2017) for a brief overview of them.

Having provided this historical and theological backdrop to the Caitanya Vaișnava tradition and the CVV, I will now describe the various resonances that the CVV's theological framework has with the previously mentioned environmentally oriented Hindu motifs and also mention some of the CVV's distinctive eco-theological motifs.

First, the CVV's theological framework also divinizes nature, albeit in its own distinctive manner. Okita has described how the CVV view of nature converges and departs from that of Advaita Vedānta, Śrī Vaișnavism, and the Mādhva Vaișnava tradition (Okita, 2009). In short, he explains that the CVV presents a unity between God and the world since $m \bar{a} y \bar{a}$, or the entirety of physical nature is not ontologically disconnected from God but is instead one of God's energies (śaktis) (Okita, 2009: $10 ; 13)$, and this is a view that I argue is closely aligned with the theological framework of Śrī Vaiṣnavism. Such a view of unity thus entails that nature should not be viewed as a separate entity from God. It should also be noted that the BhP positively values $m \bar{a} y \bar{a}$ as a metaphysically and cosmologically creative force and does not devalue $m \bar{a} y \bar{a}$ by viewing it as an illusion that is ultimately meant to be dissipated once an individual attains soteriological perfection (Gupta, 2015: 71-72). Thus, just as Śrī Vaișṇavas have an ecological incentive to properly respect the world (since it is seen as the body (śarira) of God), I argue that spiritual practitioners within the CVV too have this incentive to treat nature with respect, since the physical world is ontologically rooted in God as an expression of one of God's saktis and thus deserves to be revered.

Moreover, it is worth highlighting that in $B h G 7.4^{20}$, Kṛṣna states that the material elements, earth, water, fire, air, and space, are aspects of nature (prakrti), which belongs to Krșṇa. Notably, here Kṛșna uses the possessive "my" (me) in relationship to prakrti. This usage of "my" reveals another way for individuals within the CVV to conceive of nature-as Krșna's property. When one views nature as Kṛṣna's property, they have a further theological imperative to respect it-since the

\footnotetext{
${ }^{20}$ bhūmir āpo 'nalo vāyuh kham mano buddhir eva ca / ahan̄kāra iț̄yam me bhinnā prakṛtir aștadhā // (Schweig, 2010: 298).
} 
proprietor of nature is God and not us, we should treat nature just as respectfully as we would treat another's possessions. Thus, it is no surprise to find the contemporary CVV theologian A.C. Bhaktivedānta Swami Prabhupāda (c. 1896-1977 CE) emphasizing the importance of revering nature by his stating that "there is full cooperation between [humans] and God and [humans] and nature, and this conscious cooperation between [humans] and nature...can bring about happiness, peace and prosperity in the world" (Prabhupāda, 1998: 173).

It is worth adding that a distinctive motif within the CVV's theological framework is the notion of yukta-vairägya, which David Haberman translates as "proper renunciation" (Haberman, 2003: 75). This concept is stated by Rūpa Gosvāmin in these terms, "the renunciation of a person who suitably employs worldly objects, without attachment to them, is said to be proper. In such renunciation, there is per-

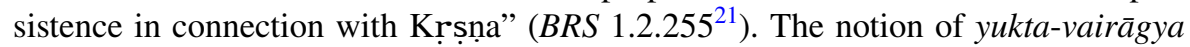
is highly significant because (1) it does not discourage worldly activity and instead sanctions and spiritualizes the utilization of material objects for the devotional service of God, and (2) it demotivates individuals from using material objects in an exploitative spirit. One positive ecological implication of (1) is that it indicates that individuals can make progress toward soteriological perfection by suitably engaging with the world, without having to physically withdraw from it to some frontiers or zones. Thus, individuals' attempts to serve God by properly taking care of nature, which is God's property and intimately connected with God, can be viewed as an integral part of their soteriological progress. Moreover, (2) it has crucial ecological implications because the capitalistic thirst for dominating the world for personal benefit is a major environmentally destructive force (Grey, 2004: 20). Therefore, the Caitanya Vaișnava who suitable and responsibly applies yukta-vairägya in order to utilize material objects in a non-exploitive spirit for God's service can curb their consumerist proclivities and significantly reduce their ecological footprint.

However, it is important to bear the negative implications of the yukta-vairägya principle in mind as well. For example, presently, within the International Society for Krishna Consciousness (ISKCON), an institution within the CVV that Prabhupāda founded in New York in 1966, many travelling lecturers employ the yukta-vairāgya principle by availing themselves of airplanes in order to travel the globe more efficiently. From one perspective, such air-travel is aligned with the aim of yukta-vairāgya since these lecturers utilize airplanes in order to significantly increase the number of individuals who hear these lecturers glorify God. Yet, from another perspective, such air-travel, though enacted in the spirit of the yuktavairāgya principle, leaves behind an enormous ecological footprint and contributes to environmental degradation. Thus, the yukta-vairāgya principle can inspire either positive or negative ecological action, and individuals who do utilize this principle should exercise caution so that they do not neglect to consider the ecological ramifications of its application. Nevertheless, by understanding the ecological benefits of its successful application and by cognizing the environmental consequences of its

\footnotetext{
21 anāsaktasya vișayān yathārham upayuñjatah / nirbandhaḥ kṛṣna-sambandhe yuktam vairāgyam ucyate // (Gosvami \& Das 1946 [1979]). Note, a page number for this reference is not available since this was retrieved from the Gaudīya Grantha Mandīra website.
} 
misuse, individuals could more responsibly apply this principle in order to ameliorate the environmental crisis.

Within the CVV's praxis, it is worth highlighting how the yukta-vairägya principle has been applied in a manner that promotes environmental sustainability. For instance, ISKCON pairs the principle of yukta-vairāgya with Gandhian economics in its "anticipatory communities" that seek to combat the current ecological crisis by proactively reorienting themselves to sustainable patterns of ecological development and by consciously seeking to embody certain beneficial ecological and social virtues (Rasmussen, 2013: 227). Kenneth Valpey considers ISKCON to have developed at least two such anticipatory communities, Mayapur Chandrodaya Mandir (MCM) in India and New Vraja Dhama (NVD) in Hungary (Valpey, 2020: 213). Christopher Fici has also described the Govardhan Eco-Village in India as an "anticipatory community" (Fici, 2020: 184). The Govardhan Eco-Village is particularly significant, I argue, because it applies the principle of yukta-vairägya by developing its infrastructure through modern technology, rather than by shying away from the usage of such technology in lieu of more traditional methods of development. One example of the Govardhan Eco-Village's application of modern technology is its usage of Compressed Stabilized Earth Bricks, made from indigenous mud, for all of its architectural structures (Fici, 2020: 193). Since these bricks can be formed by hand-pressing locally available indigenous mud, stone dust, lime, and cement, their production does not require that they be heated in a brick kiln. Crucially, their production requires only $2 \%$ of the energy that conventionally fired bricks need (Fici, 2020: 193). Thus, the production of these bricks illustrates the positive environmental consequences of directly incorporating modern technology into attempts for ecological betterment.

It is also worth noting that the yukta-vairāgya principle has also been applied by other religious institutions within the C VV. For instance, within the Gaudīya Mātha, which was initially formed on September 6, 1920, and encompasses a variety of different sub-institutions, there are various ecologically oriented projects across the world. One such project, Ananda-Dham, in Golino, Germany, is being developed by members of the International Pure Bhakti Yoga Society, which was started in 2004 by Bhaktivedanta Narayana Goswami (1921-2010 CE). In Ananda-Dham, the yukta-vairägya principle is applied through the construction of small cottages that enable its community members to sustainably live off the land. Moreover, community members also employ technology to assist with their agricultural efforts.

The abovementioned anticipatory communities and ecological projects are notable because they appeal to urbanized individuals, especially in the Western countries. This is significant because, if we recall, one of the limitations of Gandhian economics is that it is of little appeal to urbanized demographics. The success of these anticipatory communities and ecological projects thus provide greater insight into how Gandhian economics can be applied in present-day urbanized contexts. We might surmise that the yukta-vairāgya principle, in conjunction with a well-developed infrastructure, can enhance the appeal of sustainable communities that adhere to Gandhian economic principles.

Yet, before drawing any conclusions, it is also important to point out that CVV institutions in the Western countries have a significant portion of Western followers 
in their demographics, many of whom are converts to the faith. Thus, there is some uncertainty as to whether (a) the CVV's theological framework and eco-theological motifs directly inspire environmental activism, or (b) environmentally oriented Westerners are, for reasons that may or may not even be connected to ISKCON's eco-theological framework, drawn to institutions within the CVV and carry their ecological proclivities with them into CVV institutions. A comprehensive analysis of (a) and (b) is beyond the scope of this paper. Nevertheless, CVV institutions have had success in drawing urbanized Westerners to ecological projects, and by drawing attention to some of the key eco-theological motifs that inform these projects' praxis and ethos, I hope to illuminate the way for further research into the CVV's ecological dimensions and how these can provide a blueprint for a successful application of Gandhian economics in urbanized contexts.

Finally, it is worth adding that the CVV, like other Vaișnava traditions, places an emphasis on developing a mood of service toward God. An iconic verse that illustrates this mood is "I am the servant of the servant of the lotus feet [of God]" (CC $2.13 .80 \mathrm{~b}^{22}$ ). In this verse, the insistence on servitude is highlighted to an extreme degree, so much so that the devotee does not even wish to serve God directly, but instead strives to serve the servant of God's servant. This motif of service to God, and more specifically, service to God through service to God's servant, has significant ecotheological implications. For instance, within the CVV, the river Yamunā is regarded as one of Krṣ̣na's greatest devotee-servants (Haberman, 2006: 197-199). Thus, a Caitanya Vaișnava would have an incentive to serve the Yamunā given her ontological role, and one means of such service can be to cleanse the Yamunā of pollution.

However, one problematic feature of the motif of service is that a devotee may view the objects of their service as too pure to be contaminated-a tendency that we have witnessed across Hindu traditions. As Haberman has shown, this attitude is indeed prevalent among the inhabitants of Vṛndāvana, and many of these inhabitants do not believe that the Yamunā could be contaminated due to her purity (Haberman, 2006: 131-140). Thus, a practical and effective application of the motif of service will require that Caitanya Vaiṣnavas do not sacralize the objects of their service to the extent that they become unaware of the realities of pollution or fail to take action against environmentally destructive forces. Unfortunately, a comprehensive description of how the motif of service can be successfully applied is beyond the scope of this paper, although by drawing attention to this motif, I hope to pave the way for future discourse pertaining to it.

\section{Demonstrating the CVV's Theological Responses to Pan-Hindu Eco-Theological Challenges}

Having explained some of the ecologically oriented features of the CVV's conceptual framework and praxis, I will now explain how this framework can provide responses to some of conceptual difficulties that I have previously described.

${ }^{22}$ kintu prodyan-nikhila-paramānanda-pūrnāmrtābdher gopī-bhartu $\boldsymbol{h}$ pada-kamalayor dāsadāsānudāsa h //. (Kavirāja and Prabhupāda 1998b: 1984). Only the bolded text is translated. 
Recall that the efficacy of Hindu conceptual resources as tools for environmental amelioration can be undermined when these resources promote an otherworldly attitude that discourages environmental activism. Since individuals within the CVV strive to make Kṛșna the locus of their focus and existential commitment, rather than worldly improvement itself, one could charge the CVV with having an otherworldly orientation. I grant that an otherworldly theological orientation can demotivate environmental activism if worldly activity is designated as a distraction from soteriological pursuits. However, I deny that a text's or a tradition's otherworldly orientation is necessarily environmentally detrimental in itself. Rather, it is how this attitude is interpreted by religious practitioners that can lead to positive or negative ecological consequences. Yet, there can indeed be interpretations of otherworldly theological frameworks that can promote ecological activism and thus produce positive ecological consequences. For instance, as I have previously mentioned, Mumme has argued for an interpretation of Śrī Vaiṣnavism that encourages worldly participation as well as environmentally oriented activism, and Rambachan too has argued for an interpretation of Advaita Vedānta that incentivizes social activism. Thus, even though the two abovementioned traditions have been charged with the accusation of having an otherworldly orientation that deters worldly involvement, the work of the two scholars mentioned above illustrates that a suitable interpretation of a theological framework can demotivate otherworldly tendencies and instead promote social and environmental activism.

Recall that I have previously argued that the CVV's theological framework provides a theological imperative for Caitanya Vaiṣnavas to properly care for the environment, since nature is ontologically connected with God and under God's proprietorship. I now argue that the CVV's theological resources can also prevent its otherworldly orientation from deterring Caitanya Vaiṣnavas from engaging in environmental activism. For instance, according to the yukta-vairāgya principle, undertaking activity in the world through the use of material objects can be a means by which one can serve God and thus qualify oneself to be able to attain the ultimate soteriological aim of preman. This is best illustrated through the anticipatory communities that I have described previously.

Furthermore, like the Śrī Vaișnava tradition, the CVV, due to its adherence to the $B h G$, supports the principle of loka-sangraha, which can be translated as "keeping the world together." The loka-sangraha principle is described in $B h G 3.20^{23}$, where Kṛșna urges his devotee Arjuna to adhere to this principle. The loka-sangraha principle is significant because it indicates that a Caitanya Vaișnava is not above performing activities that benefit humankind. Rather, even if one is a devotee who is as intimately connected to Kṛṣna as Arjuna, one still has an imperative, given by Krșna himself, to work for the welfare of the world. ${ }^{24}$

Moreover, it is worth re-emphasizing that according to the CVV's theological framework, nature is sacralized and re-envisioned as God's property. Thus, while pursuing preman, a Caitanya Vaiṣnava cannot neglect to properly respect the earth,

\footnotetext{
${ }^{23}$ karmaṇaiva hi samisiddhim āsthitā janakādayaḥ / loka-sañgraham evāpi sampaśyan kartum arhasi // (Schweig, 2010: 290).

${ }^{24}$ I thank an anonymous reviewer who suggested looking further into the loka-sarigraha principle.
} 
since it is (a) the very property of the beloved whom the Caitanya Vaiṣnava wishes to please and develop love for. The earth, or more precisely, the totality of nature, is also (b) ontologically connected with God. Thus, a Caitanya Vaișnava cannot develop a callous attitude toward the earth, for if they were to do so, they would, by virtue of nature's connection with God, be developing a callous attitude toward Kṛṣna himself, even if indirectly.

Furthermore, it is worth highlighting that within the CVV's theological framework, the principle of Krṣna-bhakti is ascribed greater importance than the principle of liberation from the world (mukti). Thus, Kṛ̦ṇa's greatest devotees do not desire liberation from this world but instead simply wish to serve Kṛșna wherever Kṛṣna may want them to be, even if it is within the physical world. This principle is best illustrated by one of Caitanya's famous verses, "O Lord of the universe, I do not desire wealth, followers, beautiful women, nor poetic ability. O Lord, may I only have motiveless devotion for you birth after birth (janmani janmani)" (CC $3.20 .29^{25}$ ). Here, the words janmani janmani are highly significant, for they indicate that Caitanya and Caitanya's followers who seek to imbibe his devotional mood (bhāva) are willing to serve God across birth after birth, thus subordinating mukti to the principle of Krṣna-bhakti. Therefore, such a devotionally oriented attitude, I argue, shifts one's focus away from primarily wanting to transcend this world and instead, re-orients one to serving God, even if, or especially if, such service requires one to stay within the physical world. Thus, with such a theo-centric perspective, serving God by properly interacting with the world is viewed as a nobler ideal than merely neglecting the world by seeking to abandon it.

However, a Caitanya Vaiṣnava could primarily be motivated to perform bhakti because its successful performance can enable that Caitanya Vaișnava to be transferred to Kṛșna's abode beyond this worldly realm. For instance, $B h G 8.6^{26}$ states that an individual's destination after death is determined by the state of being that they remember at the time of their death. $B h G 8.8^{27}$ also adds that one who constantly thinks of Kṛṣna goes to him. Furthermore, $B h G 15.6 \mathrm{~b}^{28}$ notes that one who attains to Krșna's abode does not return to this world again, and thus, the successful performance of bhakti grants one liberation from this world, even if such liberation is a secondary consequence of the performance of bhakti. Therefore, given the inclusion of mukti within bhakti, one could perform the latter in hopes of achieving the former, thus giving one's performance of bhakti a greater otherworldly orientation than a Caitanya Vaișnava who imbibes Caitanya's mood.

Admittedly, the Caitanya Vaișnava who is motivated by mukti may have a greater otherworldly orientation than the Caitanya Vaișnava who is motivated by bhakti. However, there are a few points to take in consideration with regards to such a Caitanya Vaiṣnava. First, such a Caitanya Vaiṣnava might have gravitated

\footnotetext{
${ }^{25}$ na dhanam na janam na sundarịm kavitām vā jagad-īśa kāmaye / mama janmani janman̄iśvare bhavatād bhaktir ahaitukī tvayi // (Kavirāja and Prabhupāda 1998c: 2207).

26 yam yam vāpi smaran bhāvam tyajaty ante kalevaram / tạ̣ tam evaiti kaunteya sadā tad-bhāvabhāvitah // (Schweig, 2010: 300).

27 abhyāsa-yoga-yuktena cetasā nānya-gāminā / paramam purușam divyam yāti pārthānucintayan // (Schweig, 2010: 300).

28 yad gatvā na nivartante tad dhāma paramaì mama // (Schweig, 2010: 315).
} 
toward a spiritual discipline with an otherworldly orientation even if they were not to be a Caitanya Vaișnava-given the CVV's emphasis on bhakti rather than mukti, it would be odd for a Caitanya Vaișnava to develop an interest in mukti unless they were already predisposed to seek it out. In such a case, it is possible and even highly likely that this individual would not exercise much concern for the environment regardless of the spiritual discipline they undertake. Thus, if such a Caitanya Vaișnava, who is motivated primarily by mukti, was going to be more focused on otherworldly concerns regardless of the spiritual discipline they choose, then it is nevertheless beneficial for them to be affiliated with the CVV. This is because by adhering to the CVV's theological framework, the mukti-oriented Caitanya Vaișnava is incentivized to adhere to the other environmentally oriented motifs contained within this framework, such as valuing nature as ontologically connected to God and seeing nature as God's property. Thus, such a Caitanya Vaișnava is still incentivized to act in a manner that is beneficial for the earth, even if their primary aim is otherworldly.

It is now worth drawing attention to the CVV's sacralization of nature and the problems associated with this motif. For instance, within Krṣna-centered devotionalism, there are certain geographical entities that are associated with Kṛ̣na (such as the Yamunā and Mount Govardhana), and these entities are ascribed greater ontological and theological importance than other geographical entities (Haberman, 2006, 2020). As I have mentioned before, when certain geographical entities are designated as sacred, there is a tendency to devalue the importance of other geographical entities that are, by comparison, viewed as more profane.

I argue that although the CVV sacralizes certain natural entities, it has the theological resources needed to prevent incentivizing neglect of "ordinary" natural entities. For instance, as I have previously noted, according to the CVV's theological framework, all of nature can be viewed as sacred and worthy of respect since it is (a) ontologically connected with God as one of God's śaktis and (b) under the proprietorship of God. Thus, Caitanya Vaișṇavas have an incentive to treat all geographical entities with respect and not merely those that are invested with a special religious significance due to their association with Kṛșna. A clear understanding of the sacrality of nature and God's proprietorship over it can help dissuade individuals from selectively designating certain natural sites and entities as sacred and other such sites as profane. If the entirely of nature is sacred and under the proprietorship of God, then there is no justification for the mistreatment of any natural entities, since even "ordinary" ones without a direct connection to a particular holy site of pilgrimage or entity such as the Ganges are sacred by virtue of being connected to God and under the possession of God.

Nevertheless, one might argue that the CVV produces a gradation of sacrality for natural entities by assigning differing ontological values to these entities. Thus, within this hierarchy of sacrality, natural entities like the Yamunā and Mount Govardhana would be given greater focus, whereas other natural entities like "ordinary" rivers and trees would receive less attention. Hence, a Caitanya Vaișnava may view all of nature as sacred, but neglect most of nature as a whole because their attention is redirected toward the relatively few sacred sites that are associated with Kṛṣna. I am aware that a Caitanya Vaiṣnava could develop a tendency to neglect the 
natural entities that they deem to be lower on their hierarchy of sacrality. However, I argue that with the correct understanding of the CVV's theological framework, a Caitanya Vaișnava would recognize that even the "least sacred" natural entities are held to be sacred and under the possession of God nonetheless and thus deserving of proper care. Thus, while they may pay heightened attention to the Yamunā or Mount Govardhana, they still have an imperative to value and properly respect all of nature, even if certain natural entities are, in relationship to sacred sites connected with Kṛșna, less sacred.

Furthermore, it is worth highlighting that the CVV's theological framework can also perpetuate the tendency to view nature as a damsel in distress that must be rescued, due to its acceptance of the $B h P$ and the narratives therein where the earth is rescued by male deities. The CVV's theological framework, due to elevating the ontological status of feminine entities (like the Yamunā and material nature as a whole), may also exhibit the tendency to view such entities as self-sacrificing, thus justifying a lack of concern for them. Unfortunately, it is beyond the scope of this paper to also address these conceptual challenges in extensive depth. Nevertheless, I hope that the CVV's eco-theological motifs that I have delineated thus far can spark further deliberation on how the CVV might prevent such challenges.

\section{Conclusion}

In this article, I have described the CVV's various eco-theological motifs and have attempted to illustrate how they can be drawn upon as conceptual resources for environmental amelioration. I have also noted that the CVV's eco-theological framework is beset with some of the same conceptual difficulties that also pertain to pan-Hindu eco-theological motifs. However, I have attempted to demonstrate how the CVV's theological framework provides the eco-theological resources needed to alleviate some of these conceptual difficulties. Specifically, I have paid heightened focus to (a) how the CVV's theological framework can offset the tendency to neglect worldly activity in pursuance of otherworldly goals and (b) how this framework can provide an imperative for Caitanya Vaiṣnavas to respect all of nature and not merely designate only certain natural sites to be sacred.

Nevertheless, there is room for improvement. For instance, the CVV is not free from the tendency to view certain natural entities are too pure to be sacred. Moreover, the yukta-vairāgya principle, though capable of producing positive ecological benefits, carries the potential for misuse as well and must thus be applied very carefully in order to lead to desirable ecological consequences. Furthermore, additional work remains to be done on how the CVV can respond to the damsel in distress challenge and avoid the tendency to view feminine entities as self-abnegating. However, by highlighting the CVV's eco-theological dimensions, I hope that I have been able to at least help pave the way for meaningful dialogue that can help address some of these environmentally detrimental practices. In the meantime, I believe that in the midst of a climate catastrophe, the CVV's eco-theological conceptual resources cannot be neglected and must be employed as effectively as possible. 


\section{Declarations}

Conflict of Interest The author declares no competing interests.

Open Access This article is licensed under a Creative Commons Attribution 4.0 International License, which permits use, sharing, adaptation, distribution and reproduction in any medium or format, as long as you give appropriate credit to the original author(s) and the source, provide a link to the Creative Commons licence, and indicate if changes were made. The images or other third party material in this article are included in the article's Creative Commons licence, unless indicated otherwise in a credit line to the material. If material is not included in the article's Creative Commons licence and your intended use is not permitted by statutory regulation or exceeds the permitted use, you will need to obtain permission directly from the copyright holder. To view a copy of this licence, visit http://creativecommons.org/licenses/by/4.0/.

\section{References}

\section{Primary Sources}

\section{BhG}

Bhagavadgītā

BhP

Bhāgavatapurāṇa

BRS

Bhaktirasāmṛtasindhu of Rūpa Gosvāmin

$\mathrm{CC}$

Caitanya-caritāmṛta of Kṛ̣̣nadāsa Kavirāja

Manu

Manusaṃhitā

Gosvāmin, R., and Das, H. (trans.) (1946). [1979] Bhaktirasāmrtasindhu with commentaries of J̄̄va Gosvāmin, Mukunda Dāsa Gosvāmin, and Viśvanātha Cakravartin. Haribol Kutir.

Jolly, J. (comp.). (1887). Manusaṃhitā. Trurner and Co. Ludgate Hill.

Kavirāja, K., \& Prabhupāda, A. C. B. S. (trans. and commentator). (1998a). Caitanya-caritāmṛta: Ādilìlā. Bhaktivedanta Book Trust.

Kavirāja, K., \& Prabhupāda, A. C. B. S. (trans. and commentator). (1998b). Caitanya-caritāmrta: Madhya-līlā. Bhaktivedanta Book Trust.

Kavirāja, K., \& Prabhupāda, A. C. B. S. (trans. and commentator). (1998c). Caitanya-caritāmṛta: Āntyalīlā. Bhaktivedanta Book Trust.

Śāstrī, K. (ed.). (1965-1975). Bhāgavata Purāna, with multiple Sanskrit commentaries. 12 Cantos. Ahmedabad: Śrī Bhāgavatavidyāpīṭha.

Schweig, G. (trans.). (2010). Bhagavad Gita: The beloved Lord's secret love song. Harper Collins.

Tagare, G. V. (trans.), \& Shastri J. L. (ed.). (1950). Bhāgavata Purāna parts 1-5. Motilal Banarsidass.

\section{Secondary Sources}

Baroni, L., Cenci, L., Tettamanti, M., \& Berati, M. (2006). Evaluating the environmental impact of various dietary patterns combined with different food production systems. European Journal of Clinical Nutrition, 61, 279-286. https://doi.org/10.1038/sj.ejcn.1602522.

Barua, A. (2010). God's body at work: Rāmānuja and panentheism. International Journal of Hindu Studies, 14(1), 1-30. https://www.jstor.org/stable/40981281.

Blanc, E., \& Reilly, J. (2015). Climate change impacts on U.S. crops. Choices, 30(2), 1-4. https://www. jstor.org/stable/choices.30.2.03.

Bryant, E. (2006). Strategies of Vedic subversion: the emergence of vegetarianism in post-Vedic India. In P. Waldau \& K. Patton (Eds.), A Communion of subjects. Animals in religion, science, and ethics (pp. 193-203). Columbia University Press. 
Bryant, E. F. (2017). Bhakti yoga: tales and teachings from the Bhagavata Purana. North Point Press.

Burgat, F. (2004). Non-violence towards animals in the thinking of Gandhi: The problem of animal husbandry. Journal of Agricultural and Environmental Ethics, 14, 223-248.

Chapple, C. K. (1998). Toward an indigenous Indian environmentalism. In L. E. Nelson (Ed.), Purifying the earthly body of God: Religion and ecology in Hindu India (pp. 13-37). SUNY Press.

Chapple, C. K. (2000). Introduction. In C. K. Chapple \& M. E. Tucker (Eds.), Hinduism and ecology: Intersections of earth, sky, and water (pp. xxxiii-xlix). Harvard University Press.

Dwivedi, O. P. (2006). Hindu Religion and environmental well-being. In R. S. Gottlieb (Ed.), The Oxford Handbook of Religion and Ecology. Oxford University Press.

Fici, C. (2020). Where the earth meets the Divine is the root of devotion: anticipatory community and regenerative ecotheology in the time of climate catastrophe. Ph.D diss., Union Theological Seminary.

Forstheofel, T. A., \& Humes, C. A. (2005). Introduction: making waves. In T. A. Forsthoefel \& C. A. Humes (Eds.), Gurus in America (pp. 1-13). SUNY Press.

Gadgil, M., \& Guha, R. (1992). The fissured land: An ecological history of India. University of California Press.

Gottlieb, R. S. (2006). Introduction: Religion and ccology - What is the connection and why does it matter. In R. S. Gottlieb (Ed.),The Oxford Handbook of Religion and Ecology (pp. 3-19). Oxford University Press.

Guha, R. (1998). Mahatma Gandhi and the environmental movement in India. In A. Kalland \& G. Persoon (Eds.), Environmental movements in Asia (pp. 65-82). Curzon Press.

Grey, M. C. (2004). Sacred longings: The ecological spirit and global culture. Fortress Press.

Gupta, R. (2007). The Caitanya Vaisnava Vedanta of Jiva Gosvami: When knowledge meets devotion. London: Routledge.

Gupta, G. (2015). The world as illusion: Environmental implications of the doctrine of māyā. Journal of Vaishnava Studies, 24(1), 63-76.

Haberman, D. L. (trans.). (2003). The Bhaktirasāmrtasindhu of Rūpa Gosvāmin. Indira Gandhi Centre for the Arts.

Haberman, D. L. (2006). River of love in an age of pollution: The Yamuna river of northern India. University of California Press.

Haberman, D. L. (2020). Loving stones: making the impossible possible in the worship of Mount Govardhana. Oxford University Press.

Harold J. M., Hayes, W. K., Soret, S., Carter, R. L., Schwab, E. R., \& Sabaté, J. (2009). Diet and the environment: Does what you eat matter? The American Journal of Clinical Nutrition, 89(5), 1699S-1703S. https://doi.org/10.3945/ajen.2009.26736Z.

Heller, C. (1993). For the love of nature: Ecology and the cult of the romantic. In G. Gaard (Ed.), Ecofeminism: Women animals nature (pp. 219-242). Temple University Press.

Holdrege, B. (2013). The Gauḍiya discourse of embodiment: Re-visioning jũanna and yoga in the embodied aesthetics of Kṛṣna bhakti. The Journal of Hindu Studies, 6(2), 154-197. https://doi-org.ezp.lib. cam.ac.uk/10.1093/jhs/hit023.

Houben, J. (1999). To kill or not to kill the sacrificial snimal (yajña-paśu): Arguments and perspectives in Brahminical ethical philosophy. In J. Houben \& K. R. Van Kooij (Eds.), Violence denied: Violence, non-violence and the rationalization of violence in South Asian cultural history (pp. 105-183). Brill.

Jain, P. (2011). Dharma and ecology of Hindu communities: Sustenance and sustainability. Ashgate.

Jain, P. (2019). Modern Hindu dharma and environmentalism. In T. Brekke (Ed.), The Oxford History of Hinduism: Modern Hinduism (pp. 261-273). Oxford University Press.

Korom, F. (1998). On the ethics and aesthetics of recycling in India. In L. E. Nelson (Ed.), Purifying the earthly body of God: Religion and ecology in Hindu India (pp. 197-224). SUNY Press.

Klostermaier, K. (2007). A survey of Hinduism, $3^{\text {rd }}$ edition. SUNY Press.

Larson, G. J. (1989). 'Conceptual resources' in South Asia for 'environmental ethics'. In J. Callicott, B. Callicott, \& R. T. Ames (Eds.), Nature in Asian traditions of thought: Essays in environmental philosophy. SUNY Press.

Mumme, Patricia. Y. (1998). Models and images for a Vaisnava environmental theology: The potential contribution of Srivaisnavism. In L. E. Nelson (Ed.), Purifying the earthly body of God: Religion and ecology in Hindu India (pp. 133-161). SUNY Press.

Naess, A. (1973). The shallow and the deep, long range ecology movement. A summary. Inquiry, 16, 95-100.

Naess, A. (1987). Self realization: an ecological approach to being in the world. Trumpeter, 4(3), 35-42. 
Nagarajan, V. R. (1998). The earth as goddess Bhu Devi: toward a theory of 'embedded ecologies' in folk Hinduism. In L. E. Nelson (Ed.), Purifying the earthly body of God: Religion and ecology in Hindu India (pp. 269-295). SUNY Press.

Narayanan, V. (1997). 'One tree Is equal to ten sons': Hindu responses to the problems of ecology, population, and consumption. Journal of the American Academy of Religion, 65(2), 291-332. https:// www.jstor.org/stable/1465767.

Narayanan, V. (2001). Water, wood, and wisdom: Ecological perspectives from the Hindu traditions. Daedalus, 130(4), 179-206. www.jstor.org/stable/20027723.

Nelson, L. E. (1998). 'The dualism of nondualism' Advaita Vedanta and the irrelevance of nature. In L. E. Nelson (Ed.), Purifying the earthly body of God: Religion and ecology in Hindu India (pp. 61-88). SUNY Press.

Nelson, L. E. (2000). Reading the Bhagavadgita from an ecological perspective. In C. K. Chapple \& M. E. Tucker (Eds.), Hinduism and ecology: Intersections of earth, sky, and water (pp. 127-164). Harvard University Press.

Nelson, L. E. (2008). Hinduism. In S. Mittal \& G. R. Thursby (Eds.), Studying Hinduism: Key concepts and methods. Routledge.

Okita, K. (2009). The world-affirming vision of non-duality: Vaiṣnava Vedānta Contribution to Deep Ecology. The Trumpeter, 25(2), 1-32.

Okita, K. (2014). Hindu theology in early modern South Asia: The rise of devotionalism and the politics of genealogy. Oxford University Press.

Peritore, N. P. (1993). Environmental attitudes of changing elites: Challenging Western postmodernist models. Asian Survey, 33(8), 804-818.

Prabhupāda, A. C. B. S. (1998). Śrīmad Bhāgavatam: Canto 1 Part 2. Bhaktivedanta Book Trust.

Radder, A. J. (2015). Gandhian ecology and Vaishnava environmentalism. Journal of Vaishnava Studies, 24(1), 141-153.

Rambachan, A. (2006). The Advaita worldview: God, world, and humanity. State University of New York Press. Rambachan, A. (2014). A Hindu theology of liberation: not-two is not one. SUNY Press.

Rasmussen, L. L. (2013). Earth-honoring faith: religious ethics in a new key. Oxford University Press.

Reijnders, L., \& Soret, S. (2003). Quantification of the environmental impact of different dietary protein choices. The American Journal of Clinical Nutrition, 78(3), 664S-668S. https://doi.org/10.1093/ ajcn/78.3.664S.

Sardella, F. (2012). Modern Hindu personalism: The history, life, and thought of Bhaktisiddhanta Sarasvati. Oxford University Press.

Scheid, D. P. (2016). The common cosmic good: Religious grounds for ecological ethics. Oxford University Press.

Semeniuk, I. (2014). New climate change report details threats to global security, possibilities of violent conflict. The Globe and Mail. http://www.theglobeandmail.com/news/national/new-climate-changereport-details-threats-to-global-security-possibilities-of-violent-conflict/article17734823/.

Sidhva, S., \& Bailay, R.. (1997). Unhealthy air: noxious automobile fumes choke India's capital. Far Eastern Economic Review May edition, 45-46.

Singh, K. (1991). Brief Soujourn. B.R. Publications.

Sharma, A. (1998). Attitudes to nature in the early Upanisads. In L. E. Nelson (Ed.), Purifying the Earthly Body of God: Religion and ecology in Hindu India (pp. 51-60). SUNY Press.

Sherma, R. (1998). Sacred immanence: reflections of ecofeminism in Hindu tantra. In L. E. Nelson (Ed.), Purifying the earthly body of God: Religion and ecology in Hindu India (pp. 89-131). SUNY Press.

Shinn, L. D. (2000). The Inner logic of Gandhian ecology. In C. K. Chapple \& M. E. Tucker (Eds.), Hinduism and ecology: Intersections of earth, sky, and water (pp. 213-241). Harvard University Press.

Valpey, K. (2020). Cow care in Hindu animal ethics. Palgrave Macmillan.

Vidal, D., Tarabout, G., \& Meyer, E. (2003). On the concepts of violence and non-violence. In D. Vidal, G. Tarabout, \& E. Meyer (Eds.), Violence/non-violence: Some Hindu perspectives (pp. 11-26). Manohar.

Wheeler, T., \& Von Braun, J. (2013). Climate change impacts on global food security. Science, 341(6145), 508-513. https://www.jstor.org/stable/23491201.

White, L. (1967). The historic roots of our ecological crisis. Science, 155, 1250-1255.

Publisher's Note Springer Nature remains neutral with regard to jurisdictional claims in published maps and institutional affiliations. 